\author{
ANDRZEJ GRZEGORZ HARLA \\ ORCID: 0000-0001-8679-5366 \\ Uniwersytet Warszawski
}

\title{
ODWOŁANIE OD ORZECZEŃ KOMORNICZEJ KOMISJI DYSCYPLINARNEJ
}

\begin{abstract}
Abstrakt: Artykuł przestawia problematykę postępowania dyscyplinarnego przeciwko komornikom sądowym oraz odwołania od orzeczeń Komorniczej Komisji Dyscyplinarnej w świetle ustawy z 2018 roku o komornikach sądowych. Ustawa ta stanowi, że jest tylko jedna komornicza komisja dyscyplinarna, a od jej orzeczeń zainteresowane podmioty (na przykład komornik obwiniony w danej sprawie) mogą złożyć odwołanie do sądu apelacyjnego. W kwestiach nieunormowanych w tej ustawie do postępowania dyscyplinarnego odpowiednie zastosowanie mają przepisy Kodeksu postępowania karnego z 1997 roku.
\end{abstract}

Słowa kluczowe: komornik sądowy, odpowiedzialność dyscyplinarna, postępowanie dyscyplinarne, orzeczenie komisji dyscyplinarnej, odwołanie od orzeczenia komorniczej komisji dyscyplinarnej, sąd apelacyjny

\section{WSTĘP}

Obecnie obowiązująca ustawa z 22 marca 2018 roku o komornikach sądowych ${ }^{1}$, podobnie jak jej poprzedniczka z 29 sierpnia $1997 \mathrm{roku}^{2}$, zawiera wyodrębnione strukturalnie przepisy normujące odpowiedzialność dyscyplinarną komorników sądowych. Są one zawarte w jej rozdziale jedenastym, „Odpowiedzialność dyscyplinarna" (39 artykułów: od art. 222 do 260), zawierającym unormowania z zakresu prawa materialnego, procesowego i ustrojowego. W kwestiach materialno-prawnych w niej nieunormowanych stosuje się odpowiednio przepisy rozdziałów

1 Ustawa z dnia 22 marca 2018 roku o komornikach sądowych (Dz.U. z 2018 r. poz. 771; tekst jedn. Dz.U. z 2020 r. poz. 121 ze zm.) (dalej: ustawa z 2019 roku lub u.k.).

2 Ustawa z dnia 29 sierpnia1997 roku o komornikach sądowych i egzekucji (Dz.U. z 1997 r. Nr 133, poz. 882 ze zm.; tekst jedn. Dz.U. z 2018 r. poz. 1309 ze zm.) (dalej: ustawa z 1997 roku lub u.k.s.e.). 
I, II i III. Kodeksu karnego ${ }^{3}$, a w kwestiach procesowych w niej nieunormowanych - przepisy Kodeksu postępowania karnego ${ }^{4}$. Ustawa natomiast nie zawiera takiego odesłania w kwestiach ustrojowych (na przykład do Prawa o ustroju sądów powszechnych ${ }^{5}$ ), co oznacza, że jej unormowania w tym zakresie należy uznać za wyczerpujące (a ewentualne luki w ustawie usuwać w drodze wykładni).

Ustawa z 2018 roku definiuje pojęcie przewinienia dyscyplinarnego, a zarazem zawiera katalogi kar dyscyplinarnych zarówno dla komorników (art. 222 i 224 u.k.), jak i dla aplikantów oraz asesorów komorniczych (art. 225 i 226 u.k.). Normuje także termin przedawnienia dyscyplinarnego (art. 227 u.k.).

Sprawy dyscyplinarne przeciwko komornikom w pierwszej instancji rozpoznaje „komisja dyscyplinarna” (art. 222 i 230 u.k.) określana w niniejszym opracowaniu jako „Komornicza Komisja Dyscyplinarna” (KKD), a od jej orzeczeń i postanowień, kończących postępowanie w sprawie, przysługuje odwołanie do sądu apelacyjnego (art. 252 ust. 1 u.k. $)^{6}$.

Głównym celem niniejszego opracowania jest zwięzłe przedstawienie problematyki odwołania od orzeczeń $\mathrm{KKD}^{7}$ działającej na mocy wspomnianej ustawy z 2018 roku. Dodatkowo zaprezentujemy kilka refleksji ogólnych i postulatów de lege ferenda, jakie nasuwają się na tle tej problematyki. Pro ordo należy nadmienić, że nie jest celem niniejszego opracowania prześledzenie ewolucji unor-

3 Art. 223 ust. 1 u.k. stanowi, że,,w zakresie nieuregulowanym w ustawie do odpowiedzialności dyscyplinarnej komornika stosuje się odpowiednio przepisy rozdziałów I-III ustawy z dnia 6 czerwca 1997 roku — Kodeks karny (Dz.U. z 2019 r. poz. 1950 i 2128)”.

4 Art. 223 ust. 2 u.k. stanowi, że „do postępowania dyscyplinarnego w zakresie nieuregulowanym w ustawie stosuje się odpowiednio przepisy ustawy z dnia 6 czerwca 1997 r. — Kodeks postępowania karnego" (tekst jedn. Dz.U. z 2021 r. poz. 534 ze zm.).

5 Ustawa z 27 lipca 2001 roku - Prawo o ustroju sądów powszechnych (tekst jedn. Dz.U. z 2020 r. poz. 365 ze zm.); zob. w szczególności art. 110 n., dotyczące sądów dyscyplinarnych.

6 W kwestii odwołania od orzeczenia komorniczej komisji dyscyplinarnej — zob. na przykład B. Falkowski, [w:] Ustawa o komornikach sadowych. Ustawa o kosztach komorniczych. Komentarz, red. M. Simbierowicz, M. Świtkowski, Warszawa 2018, s. 555 n.; K. Gołaszewski, [w:] Ustawa o komornikach sadowych. Ustawa o kosztach komorniczych. Komentarz, red. R. Reiwer, Warszawa 2019, s. 724 n.; M. Świeczkowska-Wójcikowska, [w:] Ustawa o komornikach sadowych. Ustawa o kosztach komorniczych. Kodeks Etyki Zawodowej Komornika Sądowego. Komentarz, red. J. Świeczkowski, M. Świeczkowska-Wójcikowska, Warszawa 2020, s. 700 n.

7 Przygotowując niniejsze opracowanie, autor miał na uwadze także swoje własne doświadczenia i refleksje w zakresie orzekania w sprawach dyscyplinarnych nauczycieli akademickich, jakie zdobył pełniąc funkcję członka Komisji Dyscyplinarnej przy Radzie Głównej Nauki i Szkolnictwa Wyższego (głównie jako przewodniczący składów orzekających) przez dwie czteroletnie kadencje w latach 2013-2020. Komisja ta na gruncie ustawy z 27 lipca 2005 roku — Prawo o szkolnictwie wyższym (Dz.U. z 2017 r. poz. 2183 ze zm.) orzekała tylko w drugiej instancji, a na mocy nowej z dnia 20 lipca 2018 roku — Prawo o szkolnictwie wyższym i nauce (tekst jedn. Dz.U. z 2020 r. poz. 85 ze zm.) — orzeka zarówno w pierwszej, jak i w drugiej instancji. Do postępowania w takich sprawach $w$ zakresie nieunormowanym $w$ tych ustawach odpowiednie zastosowanie miały (art. 150 ustawy z 2005 roku) i mają (art. 305 ustawy z 2018 roku) przepisy kodeksu postępowania karnego. 
mowań postępowania w sprawach dyscyplinarnych komorników sądowych ${ }^{8}$. Tak określone cele dają dużą swobodę (ale nie dowolność) w ujęciu problemu9 .

\section{KWESTIE USTROJOWE}

De lege lata istnieje jeden organ powołany specjalnie do orzekania w sprawach dyscyplinarnych komorników sądowych; jest nim wspomniana wyżej Komornicza Komisja Dyscyplinarna (KKD) - verba legis „komisja dyscyplinarna” — która orzeka tylko w pierwszej instancji (art. 230 u.k. ${ }^{10}$ ). W drugiej instancji — jako „sąd odwoławczy” (art. 256 u.k..$^{11}$ ) — orzeka właściwy sąd apelacyjny (art. 252 ust. 1 u.k.) ${ }^{12}$, od którego orzeczeń kasacja co do zasady (lex generalis) nie przysługuje, ale na zasadzie wyjątku (lex specialis) może ją , wnieść wyłącznie Prokurator Generalny i Rzecznik Praw Obywatelskich" (art. 253 u.k.).

KKD liczy 33 członków (mogą nimi być tylko komornicy) powoływanych przez Krajową Radę Komorniczą, każdy na okres czterech lat. Komisja powołuje przewodniczącego i dwóch wiceprzewodniczących spośród swoich członków, a jej obsługę zapewnia Krajowa Rada Komornicza (art. 231 u.k.).

8 Warto wszak podkreślić, że w pierwotnej wersji ustawy z 1997 roku (u.k.s.e.) odwołania od orzeczeń komisji dyscyplinarnej rozpoznawał sąd wojewódzki — sąd pracy i ubezpieczeń społecznych (okręgowy - nowela z 24 maja 2007 roku, Dz.U. z 2007 r. Nr 112, poz. 769) (art. 75 ust. 2 u.k.s.e.), a do rozpoznania odwołania zastosowanie miały przepisy kodeksu postępowania cywilnego o apelacji (art. 75 ust. 2 i 3 u.k.s.e.). Nowela z 12 lutego 2010 roku (Dz.U. z 2010 r. $\mathrm{Nr} 40$, poz. 228) wprowadziła unormowania, w myśl których: a) od orzeczeń komisji dyscyplinarnej przysługiwało odwołanie do sądu okręgowego (art. 75 ust. 2 u.k.s.e.), b) do postępowania dyscyplinarnego w kwestiach $\mathrm{w}$ ustawie nieunormowanych odpowiednie zastosowanie miały przepisy Kodeksu postępowania karnego (art. 75 ust. 4 u.k.s.e.). Nowela z 10 września 2015 roku (Dz.U. z 2015 r. poz. 1561) wprowadziła przepis (art. 78b) stanowiący, że „do postępowania dyscyplinarnego $\mathrm{w}$ zakresie nieuregulowanym w niniejszej ustawie stosuje się odpowiednio przepisy ustawy z dnia 6 czerwca 1997 roku — Kodeks postępowania karnego" i uchyliła zarazem art. 75 ust. 2-4.

9 Konsekwencją tego założenia jest to, że dobór literatury jest selektywny (ale nie subiektywny). Ten zabieg ma także cel dodatkowy: skierować uwagę środowisk prawniczych zainteresowanych ustawowym unormowaniem problematyki zawodu komornika sądowego (w tym komorniczej odpowiedzialności dyscyplinarnej) na poruszone tu kwestie i zarazem przyczynić się do zainicjowania wymiany poglądów i dyskusji.

10 Art. 230 u.k. stanowi, że „sprawy dyscyplinarne w pierwszej instancji rozpoznaje komisja dyscyplinarna".

11 Ustawa zawiera stwierdzenie, że ,sąd apelacyjny działa jako sąd odwoławczy” (art. 256 u.k.).

12 Pro ordo warto wyraźnie stwierdzić, że ustawodawca nie przyjął koncepcji, w myśl której zarówno w pierwszej, jak i w drugiej instancji w sprawach dyscyplinarnych danego środowiska prawniczego orzekają komisje (sądy) dyscyplinarne konkretnego samorządu zawodowego — nie mamy więc do czynienia (na przykład) z kilkoma okręgowymi komorniczymi komisjami dyscyplinarnym (które orzekałyby w pierwszej instancji) i z jedną wyższą komorniczą komisją dyscyplinarną (która orzekałaby tylko w drugiej instancji). 
Członkowie KKD są niezawiśli w zakresie orzekania, a Komisja rozpoznaje sprawy dyscyplinarne w składzie trzyosobowym i we własnym zakresie dokonuje ustaleń, czy działanie komornika, asesora lub aplikanta nosi znamiona przewinienia dyscyplinarnego (art. 233 u.k.).

\section{POSTĘPOWANIE DYSCYPLINARNE W ZARYSIE}

Ze względu na to, że ustawa z 2018 roku o komornikach sądowych nie zawiera wyczerpującego unormowania postępowania dyscyplinarnego, a odpowiednie stosowanie przepisów kodeksu postępowania karnego (art. 223 ust. 2 u.k.) może sprawiać duże trudności w praktyce, pożądanym jest zwięzłe przedstawienie najważniejszych unormowań obu tych ustaw w taki sposób, aby odzwierciedlić założony przez ustawodawcę tok postępowania dyscyplinarnego (naruszenie zasad takiego postępowania daje podstawy do zgłoszenia zarzutów w odwołaniu od orzeczenia KKD). Dodatkowo przemawia za tym okoliczność, że sąd apelacyjny może udzielać członkom składu orzekającego KKD tak zwanych wytknięć (wytyków) orzeczniczych, których istota polega na „wytknięciu oczywistej obrazy przepisów" (art. 256 u.k.) $)^{13}$.

De lege lata postępowanie w komorniczej sprawie dyscyplinarnej może mieć trzy etapy: 1. przygotowawczy — „dochodzenie dyscyplinarne" 14 prowadzone przez rzecznika dyscyplinarnego, 2. rozpoznawczy obejmujący „postępowanie dyscyplinarne" 15 prowadzone przez Komorniczą Komisję Dyscyplinarną (KKD) $\mathrm{i}$,ppostępowanie odwoławcze" prowadzone przez sąd apelacyjny ${ }^{16}$ oraz 3. wyko-

13 Art. 256 u.k. stanowi, że: „1. Sąd apelacyjny działający jako sąd odwoławczy, w przypadku stwierdzenia przy rozpoznawaniu sprawy oczywistej obrazy przepisów, wytyka uchybienie danemu składowi komisji dyscyplinarnej. [...] 2. O wytknięciu uchybienia sąd apelacyjny zawiadamia Ministra Sprawiedliwości oraz Prezesa Krajowej Rady Komorniczej. 3. Odpis postanowienia zawierającego wytknięcie uchybienia dołącza się do akt osobowych komorników, którzy orzekali w składzie komisji dyscyplinarnej, o którym mowa w ust. 1".

14 „Dochodzenie dyscyplinarne” prowadzone jest przez rzecznika dyscyplinarnego — art. 240 ust. 1 u.k. stanowi, że ,rzecznik dyscyplinarny wszczyna dochodzenie dyscyplinarne z urzędu albo na wniosek [...]”. Art. 243 u.k. stanowi, że: „1. Rzecznik dyscyplinarny po uznaniu, że dowody zebrane $\mathrm{w}$ dochodzeniu dyscyplinarnym są wystarczające do wszczęcia postępowania przed komisją dyscyplinarną [czyli do wszczęcia »postępowania dyscyplinarnego« - A.G.H.], składa wniosek o ukaranie. 2. Złożenie wniosku o ukaranie przez rzecznika dyscyplinarnego wszczyna postępowanie przed komisją dyscyplinarną".

15 „Postępowanie dyscyplinarne” jest terminem ustawowym oznaczającym postępowanie prowadzone przez Komorniczą Komisję Dyscyplinarną (KKD). Wynika to z wielu unormowań ustawy z 2018 roku. Zob. na przykład art. 227 u.k. który stanowi, że: „1. Po upływie 5 lat od dnia popełnienia czynu nie można wszcząć postępowania dyscyplinarnego, a postępowanie wszczęte ulega umorzeniu. [...] 2. Bieg przedawnienia dyscyplinarnego przerywa wszczęcie dochodzenia dyscyplinarnego lub złożenie wniosku o wszczęcie postępowania dyscyplinarnego".

16 Ustawa zawiera stwierdzenie, że ,sąd apelacyjny działa jako sąd odwoławczy” (art. 256 u.k.). 
nawczy (wykonanie prawomocnego orzeczenia należy — w zależności od rodzaju orzeczonej kary — do Ministra Sprawiedliwości, Prezesa Krajowej Rady Komorniczej, prezesa właściwego sądu apelacyjnego albo do rady właściwej izby komorniczej, art. 260 u.k.).

Postępowanie dyscyplinarne jest wszczynane przez złożenie stosownego wniosku (nie może zostać wszczęte z urzędu - wniosek a contrario). Ustawa expressis verbis stanowi, że zostaje ono wszczęte albo na „wniosek o ukaranie” składany przez rzecznika dyscyplinarnego (art. 243 u.k.), albo na ,wniosek o wszczęcie postępowania dyscyplinarnego”, który „mogą złożyć 1. Minister Sprawiedliwości, 2. prezes właściwego sądu apelacyjnego, 3. prezes właściwego sądu okręgowego, 4. prezes właściwego sądu rejonowego, 5. sędzia wizytator, 6. organ samorządu komorniczego oraz 7. komornik wizytator" (art. 228 u.k.). Złożenie zarówno „wniosku o ukaranie”, jak i ,wniosku o wszczęcie postępowania dyscyplinarnego" wszczyna postępowanie przed komorniczą komisją dyscyplinarną (art. 243 ust. 2 i art. 228 ust. 2 u.k), czyli - verba legis — ,postępowania dyscyplinarne”.

Ustawa z 2018 roku zawiera przepisy określające strony postępowania dyscyplinarnego; są nimi: podmiot, który złożył wniosek o wszczęcie postępowania dyscyplinarnego, oskarżyciel, obwiniony i pokrzywdzony. Oskarżycielem w postępowaniu dyscyplinarnym jest rzecznik dyscyplinarny; jednak niezależnie od niego w postępowaniu dyscyplinarnym jako oskarżyciel może występować Minister Sprawiedliwości, prezes sądu, sędzia wizytator, organ samorządu komorniczego oraz komornik wizytator; obwinionym jest komornik, asesor albo aplikant, przeciwko któremu złożono wniosek o wszczęcie postępowania dyscyplinarnego (art. 235 ust. 1, 2 i 3 u.k). Ustawa stanowi zarazem, że obwiniony może korzystać z pomocy obrońcy, którym może być adwokat, radca prawny albo komornik; obwiniony może ustanowić najwyżej dwóch obrońców (art. 239, ust. 1 i 2 u.k.) ${ }^{17}$.

Przepisy o postępowaniu dyscyplinarnym w sprawach komorniczych mają na celu takie ukształtowanie tego postępowania, aby: a) rzeczywisty sprawca przewinienia został wykryty i pociągnięty do odpowiedzialności dyscyplinarnej, a osoba niewinna nie poniosła tej odpowiedzialności (art. 2 § 1 pkt 1 k.p.k. w zw. z art. 223 ust. 2 u.k.); b) samo zaś rozstrzygnięcie sprawy nastąpiło „w rozsądnym terminie” (art. 2 § 1 pkt 4 k.p.k. w zw. z art. 223 ust. 2 u.k.), co oznacza, że postępowanie dyscyplinarne ma być przeprowadzone sprawnie, a nie przewlekle ${ }^{18}$ (ustawa prze-

17 Warto zauważyć, że art. 77 k.p.k. stanowi, że „oskarżony może mieć jednocześnie nie więcej niż trzech obrońców".

$18 \mathrm{~W}$ kwestii relacji pomiędzy sprawnością a przewlekłością postępowania zob. na przykład A.G. Harla, Postulat sprawności postępowania a kwestia jego szybkości (art. 6 k.p.c.), [w:] Kodeks postępowania cywilnego z perspektywy pięćdziesięciolecia jego obowiązywania. Doświadczenia i perspektywy, red. W. Marszałkowska-Krześ, I. Gil, Ł. Błaszczak, Sopot 2016, s. 263-270. Zawarte w tym opracowaniu rozważania, w tym te dotyczące relacji pomiędzy pojęciami sprawności a szybkości postępowania, mają odniesienie także do innych postępowań, na przykład karnego, administracyjnego i dyscyplinarnego. 
widuje możliwość złożenia do Sądu Okręgowego w Warszawie tak zwanej skargi na przewlekłość postępowania ${ }^{19}$ ).

Postępowanie dyscyplinarne jest jawne (art. 245 ust. 2 u.k.), a Komisja rozpoznaje sprawy dyscyplinarne na rozprawie (art. 245 ust. 3 u.k.). Komisja ma ,dążyć do tego, aby sprawa została rozpoznana na pierwszej rozprawie" (art. 246 ust. 1 u.k.), a „Przewodniczący składu orzekającego podejmuje wszelkie niezbędne czynności organizacyjne zapobiegające przedawnieniu się czynu” (art. 246 ust. 4 u.k.) ${ }^{20}$.

Rozprawa dyscyplinarna odbywa się ustnie (art. 365 k.p.k. w zw. z art. 223 ust. 2 u.k.), a z jej przebiegu sporządzany jest pisemny protokół (art. 246 ust. 5 u.k.).

Przewodniczący kieruje rozprawą i czuwa nad jej prawidłowym przebiegiem, bacząc na to, by zostały wyjaśnione wszystkie istotne okoliczności sprawy (art. $366 \S 1$ k.p.k. w zw. z art. 223 ust. 2 u.k.). Przewodniczący umożliwia stronom wypowiedzenie się co do każdej kwestii podlegającej rozstrzygnięciu; jeżeli jedna ze stron zabiera głos w jakiejkolwiek kwestii, prawo głosu przysługuje również wszystkim innym stronom; obrońcy obwinionego i obwinionemu przysługuje głos ostatni (art. $367 \S 1$ i $§ 2$ k.p.k. w zw. z art. 223 ust. 2 u.k.). O przychylnym załatwieniu wniosku dowodowego strony, któremu inna strona się nie sprzeciwiła, rozstrzyga ostatecznie przewodniczący; w innych wypadkach KKD wydaje postanowienie (art. $368 \S 1$ k.p.k. w zw. z art. 223 ust. 2 u.k.). Dowody na poparcie oskarżenia powinny być w miarę możliwości przeprowadzone przed dowodami służącymi do obrony (art. 369 k.p.k. w zw. z art. 223 ust. 2 u.k.).

Rozprawę rozpoczyna wywołanie sprawy; następnie przewodniczący sprawdza, czy wszyscy wezwani stawili się oraz czy nie ma przeszkód do rozpoznania sprawy (art. 381 k.p.k. w zw. z art. 223 ust. 2 u.k.). Po sprawdzeniu obecności przewodniczący zarządza opuszczenie sali rozpraw przez świadków; biegli pozostają na sali, jeżeli przewodniczący nie zarządzi inaczej (art. $384 \S 1$ k.p.k. w zw. $\mathrm{z}$ art. 223 ust. 2 u.k.).

Przewód dyscyplinarny rozpoczyna się od zwięzłego przedstawienia przez oskarżyciela zarzutów dyscyplinarnych; jeżeli w rozprawie nie bierze udziału oskarżyciel, przewodniczący dokonuje zwięzłego przedstawienia zarzutów dyscyplinarnych; jeśli wniesiono odpowiedź na wniosek o ukaranie lub wniosek o wszczęcie postępowania dyscyplinarnego, przewodniczący informuje o jej treści (art. $385 \S 1, \S 1$ a i $\S 2$ k.p.k. w zw. z art. 223 ust. 2 u.k.). Jeżeli obwiniony bierze udział $\mathrm{w}$ rozprawie dyscyplinarnej, to po przedstawieniu zarzutów

19 Art. 248 ust. 7 u.k. stanowi, że: „7. W zakresie nieuregulowanym w ustawie do rozpoznania skargi, o której mowa w ust. 1, stosuje się odpowiednio przepisy ustawy z dnia 17 czerwca 2004 roku o skardze na naruszenie prawa strony do rozpoznania sprawy w postępowaniu przygotowawczym prowadzonym lub nadzorowanym przez prokuratora i postępowaniu sądowym bez nieuzasadnionej zwłoki (Dz.U. z 2018 r. poz. 75 oraz z 2019 r. poz. 1349)”.

20 Art. 227 ust. 1, zd. 1 u.k. stanowi, że ,po upływie pięciu lat od dnia popełnienia czynu nie można wszcząć postępowania dyscyplinarnego, a postępowanie wszczęte ulega umorzeniu”. 
dyscyplinarnych przewodniczący poucza go o prawie składania wyjaśnień, odmowy wyjaśnień lub odpowiedzi na pytania, składania wniosków dowodowych i konsekwencjach nieskorzystania z tego uprawnienia, po czym pyta go, czy ów przyznaje się do zarzucanego mu czynu oraz czy chce złożyć wyjaśnienia i jakie; po przesłuchaniu obwinionego przewodniczący poucza go o prawie zadawania pytań osobom przesłuchiwanym oraz składania wyjaśnień co do każdego dowodu (art. $386 \S 1$ i 2 w zW. z art. 223 ust. 2 u.k.).

Po przeprowadzeniu dowodów dopuszczonych w sprawie przewodniczący zapytuje strony, czy wnoszą o uzupełnienie postępowania dowodowego i w razie odpowiedzi przeczącej - zamyka przewód dyscyplinarny (art. $405 \S 1 \mathrm{w} \mathrm{zW}$. z art. 223 ust. 2 u.k.).

Stosownie do art. 249 u.k., ,jeżeli obwiniony przyznaje się do popełnienia czynu podlegającego odpowiedzialności dyscyplinarnej, komisja dyscyplinarna może, za zgodą stron, nie przeprowadzać postępowania dowodowego lub przeprowadzić je częściowo".

Po zamknięciu przewodu dyscyplinarnego przewodniczący udziela stronom głosu końcowego; jeżeli oskarżyciel ponownie zabiera głos, należy również udzielić głosu obrońcy i obwinionemu (art. $406 \S 1$ zd. 1 w zw. z art. 223 ust. 2 u.k.).

Po wysłuchaniu głosów końcowych KKD niezwłocznie przystępuje do narady (art. 408 k.p.k. w zw. z art. 223 ust. 2 u.k.), przy czym podstawę orzeczenia może stanowić tylko całokształt okoliczności ujawnionych w toku rozprawy dyscyplinarnej (art. 410 k.p.k. w zw. z art. 223 ust. 2 u.k.). Pokreślenia wymaga, że KKD kształtuje swe przekonanie na podstawie wszystkich przeprowadzonych dowodów ocenianych swobodnie $\mathrm{z}$ uwzględnieniem zasad prawidłowego rozumowania oraz wskazań wiedzy i doświadczenia życiowego (art. 7 k.p.k. w zw. $\mathrm{z}$ art. 223 ust. 2 u.k.). Niezwłocznie po ukończeniu głosowania KKD sporządza orzeczenie na piśmie (art. 412 k.p.k w zw. z art. 223 ust. 2 u.k.).

Sentencja ${ }^{21}$ każdego orzeczenia KKD ma zawierać: 1. wskazanie komisji dyscyplinarnej, która je wydała, jej członków, oskarżycieli i protokolanta; 2. datę oraz miejsce rozpoznania sprawy i wydania orzeczenia; 3. imię, nazwisko oraz

21 Warto przypomnieć, że pierwszy polski k.p.k. z 1928 roku (Dz.U. z 1928 r. Nr 33, poz. 313) posługiwał się zestawem dwóch pojęć: „sentencja wyroku” i „uzasadnienie wyroku” (art. 363-368 i 371-378). Jego następca — k.p.k. z 1969 roku (Dz.U. z 1969 r. Nr 13, poz. 96) — zgubił termin „sentencja” (wyroku) i posługiwał się już tylko zestawem pojęć „wyrok” i ,uzasadnienie wyroku" (zob. na przykład art. 359-360 i 370-371). Obecny k.p.k. z 1997 roku (Nr 89, poz. 555; Dz.U. z 2020 r. poz. 30 ze zm.) powielił rozwiązania k.p.k. z 1969 roku (zob. na przykład art. 412-413 i 423-424). Ten stan należy ocenić negatywnie. Prawidłowa siatka pojęciowo-terminologiczna odnośnie do tej kwestii występuje nadal na gruncie procedury cywilnej zob. art. 348 i 349 k.p.c. z 1930-32 roku (Dz.U. z 1932 r. Nr 112, poz. 934); art. 325 i 3271', poprzednio art. 328 § 2 k.p.c. z 1964 roku (Dz.U. Nr 43, poz. 296; Dz. U. z 2020 r. poz. 1575 ze zm.). Pro ordo należy wspomnieć, że: 1. w ujęciu logiki każdy wyrok ma w istocie dwie części składowe: a) sentencję (zawierającą tak zwaną komparycję i tak zwany tenor, czyli rozstrzygnięcie sądu o żądaniach stron; tenor to twierdzenie/teza, którą należy udowodnić, albowiem teza nieudowodniona 
inne dane określające tożsamość obwinionego; 4. przytoczenie opisu i kwalifikacji prawnej czynu, którego popełnienie oskarżyciel zarzucił obwinionemu; 5. rozstrzygnięcie komisji dyscyplinarnej; 6 . wskazanie zastosowanych przepisów ustawy (art. $413 \S 1$ k.p.k w zw. z art. 223 ust. 2 u.k.), z tym że sentencja orzeczenia skazującego ma ponadto zawierać: 1. dokładne określenie oraz kwalifikację prawną czynu przypisanego obwinionemu; 2. rozstrzygnięcia co do kary (art. $413 \S 2$ k.p.k w zw. z art. 223 ust. 2 u.k.).

Po podpisaniu sentencji orzeczenia przewodniczący ogłasza ją publicznie (odczytując jej treść); w czasie ogłaszania wyroku wszyscy obecni stoją, z wyjątkiem komisji; zgłoszenie zdania odrębnego podaje się do wiadomości, a jeżeli członek składu orzekającego, który zgłosił zdanie odrębne, wyraził na to zgodę, także jego nazwisko; po ogłoszeniu przewodniczący lub jeden z członków składu orzekającego podaje ustnie najważniejsze powody orzeczenia, chyba że na ogłoszenie nikt się nie stawił (art. $418 \S 1,2$ i 3 k.p.k. w zw. z art. 223 ust. 2 u.k.).

Uzasadnienie orzeczenia $\mathrm{KKD}^{22}$ powinno zawierać zwięzłe: 1. wskazanie, jakie fakty komisja dyscyplinarna uznała za udowodnione lub nieudowodnione, na jakich w tej mierze oparła się dowodach i dlaczego nie uznała dowodów przeciwnych; 2. wyjaśnienie podstawy prawnej orzeczenia (art. $424 \S 1$ k.p.k w zw. $\mathrm{z}$ art. 223 ust. 2 u.k.). W uzasadnieniu orzeczenia należy ponadto przytoczyć okoliczności, które KKD miała na względzie, ustalając wymiar kary (art. 424 § 2 k.p.k w zw. z art. 223 ust. 2 u.k. oraz art. 250 u.k. ${ }^{23}$ ).

jest co najwyżej hipotezą) oraz b) uzasadnienie; 2. okoliczność, że uzasadnienie de lege lata nie zawsze jest sporządzane (życiowy pragmatyzm proceduralny) w niczym nie zmienia istoty rzeczy.

${ }^{22}$ Kwestię sporządzenia uzasadnienia orzeczenia normuje art. 251 u.k., stanowiący, że „1. Komisja dyscyplinarna $\mathrm{z}$ urzędu sporządza uzasadnienie orzeczenia $\mathrm{w}$ terminie $21 \mathrm{dni}$ od dnia jego ogłoszenia. 2. Uzasadnienie orzeczenia doręcza się z urzędu stronom, Ministrowi Sprawiedliwości i Prezesowi Krajowej Rady Komorniczej. 3. Uzasadnienia orzeczenia nie sporządza się z urzędu w sprawach, w których uwzględniono w całości wniosek o ukaranie, a obwiniony przyznał się do popełnienia czynu i za zgodą stron nie przeprowadzono postępowania dowodowego lub przeprowadzono je częściowo. 4. W przypadkach, o których mowa w ust. 3, uzasadnienie orzeczenia sporządza się wyłącznie na wniosek strony, Ministra Sprawiedliwości lub Prezesa Krajowej Rady Komorniczej, zgłoszony w terminie zawitym 7 dni od dnia doręczenia orzeczenia".

${ }^{23}$ Stosownie do art. 250 u.k. „1. Komisja dyscyplinarna wymierza karę przewidzianą w ustawie według swojego uznania, bacząc, aby jej dolegliwość nie przekraczała stopnia winy obwinionego, uwzględniając stopień społecznej szkodliwości czynu oraz biorąc pod uwagę cele zapobiegawcze i wychowawcze, które kara ma osiągnąć w stosunku do obwinionego, a także potrzeby w zakresie kształtowania świadomości prawnej komorników, asesorów i aplikantów. 2. Wymierzając karę, komisja dyscyplinarna uwzględnia w szczególności motywację i sposób zachowania się obwinionego, rodzaj i stopień naruszenia ciążących na nim obowiązków, rodzaj i rozmiar ujemnych następstw czynu, właściwości i warunki osobiste obwinionego oraz jego zachowanie się po popełnieniu czynu, a zwłaszcza starania o naprawienie szkody. Komisja dyscyplinarna z urzędu bierze pod uwagę wszystkie wymierzone obwinionemu i niezatarte kary dyscyplinarne, jak też niezatarte wytknięcia, o których mowa w art. 166 ust. 4". 


\section{CHARAKTERYSTYKA ODWOŁANIA OD ORZECZENIA KOMISJI DYSCYPLINARNEJ}

Omawiając odwołanie do orzeczeń KKD, należy mieć na uwadze, że odwołanie to ma dwa znaczenia pojęciowe: jako środek zaskarżenia (odwoławczy) i jako pismo procesowe ${ }^{24}$.

Odwołanie od orzeczenia KKD (jako środek zaskarżenia) przysługuje podmiotom wymienionym w art. 252 ust. 1 u.k., czyli 1. stronom, 2. rzecznikowi dyscyplinarnemu, 3. Ministrowi Sprawiedliwości i 4. Prezesowi Krajowej Rady Komorniczej. Wniesione (skutecznie) odwołanie rozpoznaje sąd apelacyjny ${ }^{25}$ właściwy według siedziby kancelarii obwinionego komornika lub siedziby kancelarii, w której obwiniony aplikant albo asesor był lub jest zatrudniony (art. 252 ust. 1 u.k.). Należy je wnieść w (zawitym) terminie 21 dni od dnia doręczenia orzeczenia wraz z uzasadnieniem (art. 252 ust. 1 u.k.).

Ustawa expressis verbis stanowi, że „odwołanie wnosi się za pośrednictwem komisji dyscyplinarnej, która wydała zaskarżone orzeczenie albo postanowienie" (art. 252 ust. 2 zd. 1 u.k.). Jako całkowicie zbędne (i w dodatku mylące) należy uznać słowa występujące po przecinku (,która wydała zaskarżone orzeczenie albo postanowienie"), gdyż sugerują one że komisji dyscyplinarnych jest co najmniej kilka, a przecież de lege lata funkcjonuje tylko jedna (zob. wyżej pkt 2.1 ${ }^{26}$. KKD przekazuje wniesione odwołanie właściwemu sądowi apelacyjnemu w terminie nie dłuższym niż czternaście dni od dnia wpływu środka zaskarżenia (art. 252 ust. 2 zd. 2 u.k.). To termin instrukcyjny, służący realizacji postulatu sprawności postępowania. Należy wszakże mieć na uwadze ewentualne komplikacje, które mogą być spowodowane brakami formalnymi złożonego odwołania (kwestia badania formalnego pisma procesowego, o czym niżej).

Przewodniczący KKD odmawia przyjęcia odwołania, jeżeli wniesione zostało po terminie lub przez osobę nieuprawnioną; na zarządzenie odmawiające przyjęcia odwołania przysługuje zażalenie (art. 429 § 1 i 2 k.p.k. w zw. z art. 223 ust. 2 u.k.). Sąd apelacyjny pozostawia przyjęte odwołanie bez rozpoznania, jeżeli zachodzą okoliczności określone w art. 429 § 1 k.p.k. w zw. z art. 223 ust. 2 u.k. albo jeżeli przyjęcie go nastąpiło na skutek niezasadnego przywrócenia terminu; na postanowienie przysługuje zażalenie do innego równorzędnego składu sądu odwoławczego (art. 430 k.p.k. w zw. z art. 223 ust. 2 u.k.).

24 Jako że przedmiotem niniejszego opracowania jest odwołanie od orzeczeń komorniczej komisji odwoławczej, to problematyka odwołania od postanowień tej komisji, kończących postępowanie w sprawie, nie jest w nim omawiana.

25 Sąd apelacyjny rozpoznaje odwołanie na rozprawie w składzie trzech sędziów (art. 252 ust. 3 u.k.), działając jako „sąd odwoławczy” (art. 256 u.k.).

26 W kwestii wskazanego tu zbędnego fragmentu art. 252 ust. 1 u.k. - zob. na przykład B. Falkowski, op. cit., s. 555 n.; K. Gołaszewski, op. cit., s. 725; M. Świeczkowska-Wójcikowska, op. cit., s. 702. 
Odwołanie od orzeczenia komisji dyscyplinarnej (KKD) wnosi się na piśmie do sądu apelacyjnego za pośrednictwem tej komisji; strona może złożyć pisemną odpowiedź na środek odwoławczy (art. $428 \S 1$ i 2 k.p.k. w zw. z art. 223 ust. 2 u.k.). Odwołanie można cofnąć (art. 431 k.p.k. w zw. z art. 223 ust. 2 u.k.).

Odwołanie - jako pismo procesowe — ,powinno zawierać: 1. oznaczenie organu, do którego jest skierowane, oraz sprawy, której dotyczy; 2. oznaczenie oraz adres wnoszącego pismo, a także - w pierwszym piśmie złożonym w sprawie — numer telefonu, telefaksu i adres poczty elektronicznej lub oświadczenie o ich nieposiadaniu; 3. treść wniosku lub oświadczenia, w miarę potrzeby z uzasadnieniem; 4. datę i podpis składającego pismo" (art. 119 k.p.k. w zw. z art. 223 ust. 2 u.k.). Jeżeli odwołanie ,nie odpowiada wymaganiom formalnym przewidzianym w ustawie”, ,a brak jest tego rodzaju, że pismo nie może otrzymać biegu, albo brak polega na niezłożeniu należytych opłat lub upoważnienia do podjęcia czynności procesowej, wzywa się osobę, która wniosła pismo, do usunięcia braku $\mathrm{w}$ terminie siedmiu dni. W razie uzupełnienia braku w terminie pismo wywołuje skutki od dnia jego wniesienia. W razie nieuzupełnienia braku w terminie pismo uznaje się za bezskuteczne, o czym należy pouczyć przy doręczeniu wezwania" (art. 120 § 1 i 2 k.p.k. w zw. z art. 223 ust. 2 u.k.). Odwołanie, oprócz wskazanych wyżej wymagań formalnych przewidzianych dla każdego pisma procesowego, powinno zawierać ponadto:

1. wskazanie zaskarżonego orzeczenia KKD (data i sygnatura);

2. przytoczenie zarzutów odwoławczych i ich uzasadnienie;

3. przytoczenie nowych faktów i dowodów nie zgłoszonych w postępowaniu dyscyplinarnym;

4. określenie, czego domaga się odwołujący się (tak zwane wnioski odwolawcze).

Ad 1. Zaskarżone orzeczenie. Orzeczenie KKD można zaskarżyć w całości lub w części; można także zaskarżyć brak określonego rozstrzygnięcia; przedmiotem zaskarżenia może być również samo uzasadnienie orzeczenia (art. $425 \S 2$ k.p.k. w zw. z art. 223 ust. 2 u.k.). Odwołujący się może skarżyć jedynie rozstrzygnięcia lub ustalenia naruszające jego prawa lub szkodzące jego interesom, z tym że ograniczenie to nie dotyczy oskarżyciela publicznego, który ma prawo wnieść środek odwoławczy także na korzyść obwinionego (art. 425 § 3 i 4 k.p.k. w zw. $\mathrm{z}$ art. 223 ust. 2 u.k.).

Ad 2. Zarzuty odwoławcze. Zarzuty takie wraz z uzasadnieniem obowiązani są przytoczyć oskarżyciel publiczny, obrońca, a także pełnomocnik (art. $427 \S 2$ k.p.k. w zw. z art. 223 ust. 2 u.k.). Nie ma takiego obowiązku (ale ma takie prawo) obwiniony (art. $427 \S 2$ k.p.k. a contrario w zW. z art. 223 ust. 2 u.k.). Zarzuty takie mogą dotyczyć zarówno tak zwanych względnych przyczyn odwoławczych 
(art. 438 k.p.k. ${ }^{27}$ W zw. z art. 223 ust. 2 u.k.), jak i tak zwanych bezwzględnych przyczyn odwoławczych (art. 439 k.p.k. ${ }^{28}$ w zw. z art. 223 ust. 2 u.k.).

Ad 3. Nowe fakty i dowody. Odwołujący się może wskazać nowe fakty lub dowody, jeżeli nie mógł powołać ich w postępowaniu dyscyplinarnym (art. 427 $\S 3$ k.p.k. w zw. z art. 223 ust. 2 u.k.).

Ad 4.Wnioski odwoławcze. Odwołujący się powinien dokładnie określić swoje żądanie (verba legis: ,podać, czego się domaga” — art. 427 § 1 k.p.k. w zw. z art. 223 ust. 2 u.k.), czyli wnioskować: o zmianę lub o uchylenie zaskarżonego orzeczenia w całości lub w części, o uchylenie go i umorzenie postępowania, o uchylenie go i przekazanie sprawy KKD do ponownego rozpoznania (art. 437 $\S 1$ i $\S 2$ k.p.k. w zw. $z$ art. 223 ust. 2 u.k.).

Pro ordo nadmienić jeszcze warto, że: a) sąd apelacyjny rozpoznaje sprawę w granicach zaskarżenia, a jeżeli w odwołaniu zostały wskazane zarzuty stawiane rozstrzygnięciu, to również w granicach podniesionych zarzutów, uwzględniając treść art. 447 § 1-3, a w zakresie szerszym, w wypadkach wskazanych w art. 435, art. $439 \S 1$, art. 440 i art. 455 k.p.k. (art. $433 \S 1$ k.p.k. w zw. z art. 223 ust. 2 u.k.); b) sąd ten obowiązany jest rozważyć wszystkie wnioski i zarzuty wskazane w odwołaniu, chyba że ustawa stanowi inaczej (art. 433 § 2 k.p.k. w zw. z art. 223 ust. 2 u.k.).

27 Art. 438 k.p.k. stanowi, że ,orzeczenie ulega uchyleniu lub zmianie w razie stwierdzenia: 1. obrazy przepisów prawa materialnego w zakresie kwalifikacji prawnej czynu przypisanego oskarżonemu; 1a. obrazy przepisów prawa materialnego w innym wypadku niż wskazany w pkt 1 , chyba że pomimo błędnej podstawy prawnej orzeczenie odpowiada prawu; 2. obrazy przepisów postępowania, jeżeli mogła ona mieć wpływ na treść orzeczenia; 3 . błędu w ustaleniach faktycznych przyjętych za podstawę orzeczenia, jeżeli mógł on mieć wpływ na treść tego orzeczenia; 4. rażącej niewspółmierności kary, środka karnego, nawiązki lub niesłusznego zastosowania albo niezastosowania środka zabezpieczającego, przepadku lub innego środka”.

28 Art. $439 \S 1$ k.p.k. stanowi, że „niezależnie od granic zaskarżenia i podniesionych zarzutów oraz wpływu uchybienia na treść orzeczenia sąd odwoławczy na posiedzeniu uchyla zaskarżone orzeczenie, jeżeli: 1. w wydaniu orzeczenia brała udział osoba nieuprawniona lub niezdolna do orzekania bądź podlegająca wyłączeniu na podstawie art. 40; 2 . sąd był nienależycie obsadzony lub którykolwiek z jego członków nie był obecny na całej rozprawie; [...] 5. orzeczono karę, środek karny, środek kompensacyjny lub środek zabezpieczający nieznane ustawie; 6 . zapadło z naruszeniem zasady większości głosów lub nie zostało podpisane przez którąkolwiek z osób biorących udział w jego wydaniu; 7. zachodzi sprzeczność w treści orzeczenia, uniemożliwiająca jego wykonanie; [...] 9. zachodzi jedna z okoliczności wyłączających postępowanie, określonych w art. $17 \S 1$, pkt 5, 6 i $8-11 ;[\ldots]$ 11. sprawę rozpoznano podczas nieobecności oskarżonego, którego obecność była obowiązkowa". 


\section{UWAGI I REFLEKSJE DODATKOWE. POSTULATY DE LEGE FERENDA}

W ścisłym związku z problematyką komorniczej odpowiedzialności dyscyplinarnej pozostaje kwestia nadzoru nad komornikami (art. 165 n. u.k.), którego występują trzy rodzaje: judykacyjny, administracyjny oraz wewnętrzny samorządu komorniczego (art. 165 ust. 1 u.k.s.). Stosownie do art. 167 ust. 1 u.k.s., „organami nadzoru administracyjnego są: 1. Minister Sprawiedliwości; 2. prezesi właściwych sądów apelacyjnych; 3. prezesi właściwych sądów okręgowych; 4. prezesi właściwych sądów rejonowych". Problem pojawia się w art. 175 ust. 1 zd. 1 u.k., który stanowi, że „nadzór administracyjny jest sprawowany w pierwszej kolejności przez prezesa właściwego sądu rejonowego (nadzór odpowiedzialny)"29. Nadmienić należy zarazem, że w przepisach określających uprawnienia nadzorcze prezesów sądów okręgowych (art. 181 u.k.s.) i sądów apelacyjnych (art. 182 u.k.s.), a także Ministra Sprawiedliwości (art. 172 i 173 u.k.s.) nie ma określenia w kwestii „odpowiedzialnego nadzoru”. W świetle zasady logiki odzwierciedlonej w sentencji exceptio regulam firmat $(\mathrm{ERF})^{30}$ nasuwa się wniosek, że tylko nadzór prezesa sądu rejonowego jest „nadzorem odpowiedzialnym” (to termin ustawowy — art. 175 u.k.s.), a pozostałe przypadki nadzoru administracyjnego (nadzór prezesa sądu okręgowego, prezesa sądu apelacyjnego i Ministra Sprawiedliwości) są (a w każdym razie mogą być) „nadzorem nieodpowiedzialnym” ${ }^{1}$. Rzecz jasna, takie unormowanie tej kwestii jest nie do zaaprobowania. Użyty w ustawie termin ustawowy ,nadzór odpowiedzialny” (na przykład w art. 175 u.k.) powinien zostać tak szybko, jak to tylko możliwe, usunięty z ustawy albo zastąpiony innym terminem (na przykład „nadzór rejonowy”) ${ }^{32}$. Tak długo, jak to nie nastąpi,

29 Termin ten — „,nadzór odpowiedzialny” — użyty został także w art. 176 ust. 1 u.k.s., stanowiącym, że „w zakresie nadzoru odpowiedzialnego prezes właściwego sądu rejonowego”.

${ }^{30}$ Istotę i znaczenie zasady logiki zawartej w sentencji exceptio regulam firmat (ERF) lakonicznie przedstawia następujący wywód B. Gaweckiego (wyr. oryg.): „Bezkrytyczne powtarzanie utartych powiedzeń zdarza się słyszeć na każdym kroku. Na przykład wciąż się powtarza o »wyjąt$\mathrm{ku}$, potwierdzającym regutę«, chociaż chwila zastanowienia powinna by wystarczyć do zrozumienia, że to niedorzeczność. Wyjątek może tylko osłabiać regułę, ale potwierdzać jej nie może nigdy. [...] Skąd pochodzi to błędne mniemanie? Otóż w prawie rzymskim istniała formuła exceptio firmat regulam — »wyjątek ustanawia regułę«, to znaczy, że gdy jest mowa o wyjątku, to stąd możemy wnosić, że istnieje odpowiednia reguła. Skoro ktoś oświadcza na przykład, że dziś wyjątkowo spędza wieczór poza domem, to łatwo się domyślić, że zwykle (normalnie) można go zastać wieczorem w domu (taki jest jego obyczaj, reguła postępowania). Więc wyjątek niejako wskazuje na istnienie reguły, ustanawia ją (firmat), ale bynajmniej jej nie potwierdza, utwierdza, wzmacnia itp. (afirmat, confirmat, probat)". Zob. B.J. Gawecki, Propedeutyka filozofii, Warszawa 1938, s. 63-64; idem, Myślenie i postępowanie, Warszawa 1975, s. 79.

31 Trafne i ponadczasowe spostrzeżenie że ,nikt nie dał naukowcom i matematykom prawa do zmiany znaczenia powszechnie używanych słów" odnosi się także do prawników i ustawodawcy (zob. R.A. Muller, Teraz. Fizyka czasu, Warszawa 2018, s.77).

32 Można rozważyć wprowadzenie następującej siatki pojęciowo-terminologicznej: nadzór rejonowy — sprawowany przez prezesa sądu rejonowego (art. 175 u.k.), nadzór okręgowy — przez 
wspomniane unormowania ustawy z 2018 roku będą dawały podstawę do stwierdzenia, że jako zasadę ogólną — lex generalis - ustawa ta przyjęła (w myśl paremii ERF) „nadzór nieodpowiedzialny” (sprawowany przez prezesów sądów okręgowych i apelacyjnych oraz Ministra Sprawiedliwości), a jako wyjątek od tej zasady — lex specialis — „nadzór odpowiedzialny” (sprawowany przez prezesów sądów rejonowych) $)^{33}$.

Warto nadmienić, że błąd (error) tego samego typu, jak wyżej opisany, pojawił się na gruncie k.p.c. w nowym art. $4^{1}$ k.p.c. dodanym nowelą z 4 lipca 2019 roku $^{34} \mathrm{i}$ w nowej wersji art. 3 k.p.c. nadanej mu nowelą z 16 września 2011 roku $^{35}$.

Przepis art. $4^{1}$ k.p.c. stanowi, że ,z uprawnienia przewidzianego w przepisach postępowania stronom i uczestnikom postępowania nie wolno czynić użytku niezgodnego z celem, dla którego je ustanowiono (nadużycie prawa procesowego)". Odczytując treść art. $4^{1}$ k.p.c. w świetle zasady ERF, należy uznać, że ustawa (k.p.c.) ustanawia (firmat) jako zasadę ogólną (lex generalis) założenie, że podmioty postępowania cywilnego (a są nimi: organy, strony i uczestnicy postępowania, świadkowie i biegli w takim postępowaniu oraz publicznośćc ${ }^{36}$ ) mogą nadużywać prawa procesowego, chyba że ustawa przewiduje wyjątek (lex specialis). Taki właśnie wyjątek ustawa (art. $4^{1}$ k.p.c.) przewiduje (tylko) w odniesieniu do stron i uczestników postępowania cywilnego.

Tak samo jest w przypadku art. 3 k.p.c. de lege lata ${ }^{37}$, który - w świetle zasady ERF - ustanawia (firmat) jako zasadę ogólną (lex generalis) założenie, że podmioty postępowania cywilnego (organy postępowania; strony i uczestnicy postępowania; świadkowie i biegli w takim postępowaniu oraz publiczność) mogą postępować niezgodnie z dobrymi obyczajami, chyba że ustawa przewiduje

prezesa sądu okręgowego (art. 181 u.k.), nadzór apelacyjny — przez prezesa sądu apelacyjnego (art. 182 u.k.) i nadzór ministerialny — przez Ministra Sprawiedliwości (art. 172 uk.).

33 Por. na przykład A.G. Harla, Nadzór judykacyjny nad komornikiem wedtug ustawy o komornikach sadowych, [w:] Analiza i ocena ustawy o komornikach sadowych oraz ustawy o kosztach komorniczych, red. A. Marciniak, Sopot 2018, s. 187-202.

34 Ustawa z 4 lipca 2019 roku o zmianie ustawy - Kodeks postępowania cywilnego oraz niektórych innych ustaw (Dz.U. z 2019 r. poz. 1469 ze zm.).

35 Ustawa z 16 września 2011 roku o zmianie ustawy — Kodeks postępowania cywilnego oraz niektórych innych ustaw (Dz.U. z 2011 r. Nr 233, poz. 1381).

$36 \mathrm{~W}$ kwestii czwórpodziału podmiotów postępowania cywilnego na 1. organy postępowania, 2. strony i uczestników postępowania, 3. świadków i biegłych sądowych oraz 4. publiczność (w znaczeniu poszczególnych osób obecnych na sali sądowej); zob. na przykład A.G. Harla, Prawo upadłościowe i naprawcze. Zarys wyktadu, Warszawa 2011, s. 53-54.

37 Art. 3 k.p.c. otrzymał (wskutek noweli z 16 września 2011 roku) następujące brzmienie: „Strony i uczestnicy postępowania obowiązani są dokonywać czynności procesowych zgodnie z dobrymi obyczajami, dawać wyjaśnienia co do okoliczności sprawy zgodnie z prawdą i bez zatajania czegokolwiek oraz przestawiać dowody". Brzmienie art. 3 k.p.c. po nowelizacji z 1 marca 1996 roku (Dz.U. z 1996 r. Nr 43, poz. 189) było następujące: „Strony i uczestnicy postępowania składają oświadczenia o okolicznościach faktycznych i przedstawiają dowody. Obowiązani są do mówienia prawdy i do udzielania wyjaśnień bez zatajania czegokolwiek". 
wyjątek (lex specialis). Taki właśnie wyjątek ustawa (art. 3 k.p.c.) przewiduje (tylko) w odniesieniu do stron i uczestników postępowania cywilnego.

Obiektywna wykładnia powyższych przepisów (art. $3 \mathrm{i}$ art. $4^{1}$ k.p.c.) nie pozwala pominąć (zignorować) zasady ERF. De lege lata stan normatywny opisany wyżej jako sprzeczny wymaganiami etyki społecznej ${ }^{38}$ wymaga pilnej interwencji ustawodawczej (stąd płyną dwa postulaty de lege ferenda: zmiany brzmienia art. 3 k.p.c. ${ }^{39}$ i uchylenia art. $4^{1}$ k.p.c. ${ }^{40}$ ). Niewątpliwie cele, jakimi kierował się ustawodawca przy nowelizacji art. 3 (w 2011 roku) i wprowadzeniu (w 2019 roku) art. $4^{1}$ k.p.c. (chęć przeciwdziałania próbom stron i uczestników postępowania przewlekaniu postępowania polegającym na „niesumiennym lub oczywiście niewłaściwym postępowaniu" - por. art. 103 k.p.c.), w pełni zasługują na uznanie i aprobatę, ale powinny być one osiągane $\mathrm{w}$ wyniku prawidłowo realizowanych w praktyce sądowej zasady prawdy materialnej (art. 3 k.p.c.) ${ }^{41}$ i postulatu sprawności postępowania (art. $6 \S 1$ k.p.c. ${ }^{42}$, a nie poprzez wprowadzanie do ustawy procesowej (k.p.c.) regulacji zawierających mgliste i niedefiniowalne syntetycznie pojęcia „dobrych obyczajów” i „nadużycia prawa procesowego”. Analizując tę problematykę przez pryzmat psychologii i socjologii ${ }^{43}$, można stwierdzić, że wielu uczestników obrotu prawnego będzie odbierało dyspozycje art. 3 i art. $4^{1}$ k.p.c. jako swoiste próby zniechęcenia (wystraszenia?) stron i uczestników (a także ich pełnomocników procesowych) do podejmowania wielu czynności procesowych

38 Dużą wagę do zgodności stanowionego prawa z zasadami etyki społecznej przykładała Komisja Kodyfikacyjna II RP; zob. A.G. Harla, Regulacje art. 162 k.p.c. $i$ ich potencjalny wptyw na wykonywanie zobowiazań, [w:] Wykonanie zobowiązań. Księga jubileuszowa dedykowana profesorowi Adamowi Brzozowskiemu, Warszawa 2020, s. 169 (przypis 24).

39 Zob. postulat de lege ferenda zawarty w: A.G. Harla, Zasada prawdy w procesie cywilnym (art. 2 i art. 232 k.p.c.), [w:] Honeste Procedere. Ksiega Jubileuszowa dedykowana Profesorowi Kazimierzowi Lubińskiemu, red. A. Laskowska-Hulisz, J. May, M. Mrówczyński, Warszawa, 2017, s. $189-205$

${ }^{40}$ Problematyka koncepcji tak zwanego nadużycia prawa procesowego (de lege lata - art. $4^{1}$ k.p.c.) doczekała się już obszernej literatury. Zob. w szczególności opracowanie zbiorowe Nadużycie prawa procesowego cywilnego, red. P. Grzegorczyk, M. Walasik, F. Zedler, Warszawa 2019; przykładowo można wskazać na: T. Ereciński, Nadużycie praw procesowych $w$ postępowaniu cywilnym. Tezy $i$ wstęp do dyskusji, [w:] Nadużycie prawa procesowego..., s. 11 n.; A. Marciniak, Nadużycie prawa procesowego $w$ sadowym postępowaniu egzekucyjnym, [w:] Nadużycie prawa procesowego..., s. $348 \mathrm{n}$.

41 A.G. Harla, Zasada prawdy..., s. 189 n.

42 A.G. Harla, Postulat sprawności postępowania..., s. 263 n. Por. też A.G. Harla, Ciężar wspierania postepowania cywilnego przez strony i uczestników postępowania (art. 6 \& 2 k.p.c.), [w:] Księga Pamiątkowa ku czci Sędziego Sądu Najwyższego Prof. dr hab. T. Wiśniewskiego, red. T. Ereciński, Warszawa 2017, s. 195-207.

$43 \mathrm{Na}$ znaczenie psychologii i socjologii w wykształceniu prawników zwracano uwagę już w 1925 roku — zob. na przykład C. Znamierowski, O poziom studiów prawniczych, „Ruch Prawniczy, Ekonomiczny i Socjologiczny" 1925, s. 1021-1028. 
z obawy przed zastosowaniem wobec nich przez organy postępowania cywilnego różnorakich sankcji w sytuacjach nieoczekiwanych i nieprzewidywalnych ${ }^{44}$.

Ustawa z 2018 roku, tak jak jej poprzedniczka z 1997, choć zawiera przepisy o odpowiedzialności dyscyplinarnej komorników sądowych, to nie przewiduje sądownictwa dyscyplinarnego (sądów dyscyplinarnych), a orzekanie w sprawach odpowiedzialności komorników powierza organowi pod nazwą „komisji dyscyplinarnej" (art. 30 u.k.) orzekającemu tylko w pierwszej instancji. Tymczasem w przypadku innych zawodów prawniczych (sędziego ${ }^{45}$, prokuratora ${ }^{46}$, notariusza $^{47}$, adwokata ${ }^{48}$, radcy prawnego ${ }^{49}$ ) ustawy przewidują działalność (dwuinstancyjnego) sądownictwa dyscyplinarnego. Ta swoista dyskryminacja zawodu komornika sądowego (nie ma sądów dyscyplinarnych; jest tylko komisja dyscyplinarna) nie zasługuje na aprobatę - w każdym razie nie od roku 1997, kiedy to zawód komornika sądowego „wybił się na ustawodawczą niepodległość”. Stąd płynie postulat de lege ferenda, aby także w sprawach dyscyplinarnych komorników sądowych ustawa przewidywała (dwuinstancyjne) sądownictwo dyscyplinarne. W pierwszej instancji orzekać powinny okręgowe (komornicze) sądy dyscyplinarne (na przykład od dwóch do czterech), a w drugiej — jeden wyższy (komorniczy) sąd dyscyplinarny. Wówczas kwestie ustrojowe organów postępowania dyscyplinarnego poszczególnych zawodów prawniczych zostałyby jednolicie unormowane $\mathrm{w}$ takim zakresie, $\mathrm{w}$ jakim nie stoją temu na przeszkodzie istota i charakter prawny tych zawodów. Pro ordo należy jeszcze zgłosić postulat de lege ferenda, aby od orzeczeń merytorycznych i orzeczeń niemerytorycznych kończących postępowanie w sprawie postulowanego tu Wyższego (komorniczego) Sądu Dyscyplinarnego przysługiwała kasacja do Sądu Najwyższego ${ }^{50}$.

Warto jeszcze zgłosić postulat de lege ferenda dotyczący zmiany siatki pojęciowo-terminologicznej w zakresie orzeczeń komorniczej komisji dyscyplinarnej (dotyczy on także orzeczeń sądów dyscyplinarnych innych zawodów: sędziego, prokuratora, notariusza, adwokata i radcy prawnego). Otóż orzeczenia sądowe

44 Poza zakres niniejszego opracowania wykracza kwestia sankcji za zachowania, uznane przez sąd za niezgodne z dobrymi obyczajami (art. 3 k.p.c.) lub za nadużycie prawa procesowego (art. $4^{1}$ k.p.c.); w tym miejscu można wszakże nadmienić, że regulacja art. $226^{-2}$ k.p.c. (dodany nowelą z 4 lipca 2019 roku) może budzić szereg istotnych zastrzeżeń.

45 Ustawa z 27 lipca 2001 roku — Prawo o ustroju sądów powszechnych (Dz.U. z 2020 r. poz. 2072) - zob. art. $110 \mathrm{n}$.

46 Ustawa z 28 stycznia 2016 roku - Prawo o prokuraturze (Dz.U. z 2019 r. poz. 740 ze zm.) - zob. art. $145 \mathrm{i} \mathrm{n.}$

47 Ustawa z 14 lutego 1991 roku - Prawo o notariacie (Dz.U. z 2020 r. poz. 1192) — zob. art. $53 \mathrm{n}$.

48 Ustawa z 26 maja 1982 roku — Prawo o adwokaturze (Dz.U. z 2020 r. poz. 1651) — zob. art. $91 \mathrm{n}$.

49 Ustawa z 26 maja 1982 roku o radcach prawnych (Dz.U. z 2020 r. poz. 75) — zob. art. 54.

50 Tak jest na przykład w myśl art. 91a Prawa o adwokaturze z 1982 roku art. $62^{-2}$ ustawy o radcach prawnych z 1982 roku, art. 63a Prawa notarialnego z 1991 roku. 
w procesie cywilnym (k.p.c.) i w procesie karnym (k.p.k.) dzielą się na dwie zasadnicze grupy: orzeczenia merytoryczne i orzeczenia niemerytoryczne ${ }^{51}$. Pierwsze $\mathrm{z}$ nich zapadają $\mathrm{w}$ formie wyroków (lex generalis) ${ }^{52}$, a drugie - $\mathrm{w}$ formie postanowień. Orzeczenia pierwszej instancji zaskarżane są: w przypadku orzeczeń merytorycznych - apelacją (art. 167 k.p.c.; art. 444 k.p.k.); w przypadku orzeczeń niemerytorycznych — zażaleniem (o ile ustawa przewiduje ich zaskarżalność; art. 394 k.p.c.; art. 459 k.p.k.). Płynie stąd wniosek, aby orzeczenia merytoryczne sądów dyscyplinarnych były wydawane w formie wyroków, a ich orzeczenia niemerytoryczne - w formie postanowien.

Nie od rzeczy jest wspomnieć o tym, że po odzyskaniu przez Polskę niepodległości w listopadzie 1918 roku w prawie polskim przestrzegane były wspomniane wyżej uwarunkowania teoretyczne. Jako przykład można wskazać dekret z 24 grudnia 1918 roku w przedmiocie statutu tymczasowego Palestry Państwa Polskiego ${ }^{53}$, który $\mathrm{w}$ art. 49 przewidział dla merytorycznych orzeczeń dyscyplinarnych formę wyroku wydawanego przez (adwokacki) sąd dyscyplinarny (art. 42). Dla merytorycznych orzeczeń sądów dyscyplinarnych formę wyroku przewidziały także art. 163 Prawa o ustroju sądów powszechnych z 6 lutego 1928 roku ${ }^{54}$, art. 83 Prawa o ustroju adwokatury z 7 lipca 1932 roku $^{55}$, art. 51 Prawa o notariacie z 27 października 1933 roku $^{56}$, art. 143 Prawa o ustroju adwokatury z 4 maja 1938 roku $^{57}$ Warto zwrócić uwagę na okoliczność, że w niektórych przepisach o odpowiedzialności dyscyplinarnej był użyty (i słusznie ${ }^{58}$ ) termin „sentencja wyroku" 59 .

Można jeszcze zgłosić postulat de lege ferenda, aby środek zaskarżenia od wyroków sądów dyscyplinarnych pierwszej instancji był określany nie jako „odwołanie", ale jako „,apelacja"60.

51 Gwoli ścisłości: czym innym jest rodzaj orzeczenia sądowego (merytoryczne albo niemerytoryczne), a czym innym - forma, w jakim ono zapada (są dwie zasadnicze formy orzeczeń sądów cywilnych i karnych: wyroki i postanowienia).

$52 \mathrm{Na}$ zasadzie wyjątku (lex specialis) orzeczenia merytoryczne są wydawane w formie nakazów zapłaty (art. $353^{1}$ k.p.c.). Szczególną formą orzeczenia merytorycznego jest także „wyrok nakazowy" (art. 500 k.p.k.).

53 Dziennik Praw Państwa Polskiego z 1918 r. Nr 22, poz. 75.

54 Dz.U. z 1928 r. Nr 12, poz. 93.

55 Dz.U. z 1932 r. Nr 86, poz. 733.

56 Dz.U. z 1933 r. Nr 84, poz. 609.

57 Dz.U. z 1938 r. Nr 33, poz. 289.

58 Zob. przypis 21.

59 Na przykład art. 49 Dekretu z 1918 roku o tymczasowym statucie Palestry Państwa Polskiego; art. 163 Prawa o ustroju sądów powszechnych z 1928 roku; art. 83 Prawa o ustroju adwokatury z 1932 roku, art. 143 Prawa o ustroju adwokatury z 1938 roku.

60 Tak było na przykład w myśl art. 144 - Prawa o ustroju adwokatury z 1938 roku. 


\section{ZAKOŃCZENIE}

Od tego, jak rzeczywiście działa sądownictwo dyscyplinarne poszczególnych zawodów prawniczych (sędziów, prokuratorów, komorników, adwokatów, radców prawnych i notariuszy), zależy poziom zaufania społeczeństwa do wymiaru sprawiedliwości i obrotu prawnego. Na prawidłowe działanie sądownictwa dyscyplinarnego z pewnością duży wpływ ma jakość unormowań ustawowych w kwestii odpowiedzialności dyscyplinarnej. Jeżeli jednak nie ma lub nie będzie woli sprawnego przeprowadzenia efektywnego i rzetelnego postępowania $\mathrm{w}$ sprawie dyscyplinarnej (na wszystkich jego etapach: przygotowawczym, rozpoznawczym i wykonawczym), to nawet najlepsze unormowania ustawowe okażą się mało lub wcale nieefektywne.

Ustawa z 2018 roku o komornikach sądowych kładzie duży nacisk — i słusznie - na „uwzględnienie konieczności zapewnienia należytego wykonywania zadań państwa w zakresie sprawnej, skutecznej i rzetelnej egzekucji sądowej" (art. 1 ust. 1 u.k.). $Z$ uznaniem należy przyjąć to, że nie ma $\mathrm{w}$ tej regulacji ani słowa o „szybkości” postępowania. Jak wzmiankowano wyżej, postępowanie ma być de iure skuteczne i sprawne, a jest takie tylko wtedy, gdy nie jest przewlekłe; ocena tak zwanej szybkości postępowania jest zbyt subiektywna i emocjonalna, aby mogła być miarodajnym kryterium oceny działalności organu postępowania. Realizacja tak zwanej zasady szybkości postępowania (por. art. 6 § k.p.c. in fine) w praktyce skutkuje najczęściej nakręcaniem swoistej spirali pośpiechu i nerwowości w konkretnej sprawie, co siłą rzeczy przekłada się (często w ledwie zauważalny sposób) niekorzystnie także na inne sprawy.

Tymczasem ustawa z 2018 roku stanowi, że „nadzór odpowiedzialny” (czyli nadzór sprawowany przez właściwego prezesa sądu rejonowego) polega przede wszystkim na „ocenie szybkości, sprawności i rzetelności postępowania” egzekucyjnego, które prowadzi komornik (art. 175 ust. 1 pkt 1 u.k.). Tu nasuwa się postulat de lege ferenda, by w art. 175 ust. 1 pkt 1 u.k. zastąpić „,szybkość” ,skutecznością".

Mając na uwadze powyższe, należy uznać, że także w przypadku postępowań sądowych i dyscyplinarnych wskazane jest kierowanie się maksymą cesarza Augusta - festina lente (śpiesz się powoli) ${ }^{61}$.

61 W. Kopaliński, Stownik wyrazów obcych i zwrotów obcojęzycznych z almanachem, Warszawa 2003, s. 169;

C. Michalunio, Dicta. Zbiór łacińskich sentencji, przystów, zwrotów i powiedzeń, Kraków 2004, s. 181. 


\title{
APPEAL AGAINST THE DECISIONS OF THE COURT ENFORCEMENT OFFICER'S DISCIPLINARY COMMISSION
}

\author{
Summary
}

The article presents the issues of disciplinary proceedings against court enforcement officers and appeals against the decisions of the Court Enforcement Officer's Disciplinary Commission under the 2018 Act of court enforcement officers. The act stipulates that there is only one court enforcement officer's commission and iterested entities (e.g. accused bailiff in a given case) may appeal to the court of appeal against its decisions. In matters not covered by the Act, the rules of the Code of Criminal Procedure of 1997 apply accordingly.

Keywords: court enforcement officer, disciplinary liability, disciplinary proceedings, decision of the disciplinary commission, appeal against the decision of the court enforcement officer's disciplinary commission, court of appeal

\section{BIBLIOGRAFIA}

Ereciński T., Nadużycie praw procesowych w postępowaniu cywilnym. Tezy $i$ wstęp do dyskusji, [w:] Naduzycie prawa procesowego cywilnego, red. P. Grzegorczyk, M. Walasik, F. Zedler, Warszawa 2019, s. 11-18.

Falkowski B., [w:] Ustawa o komornikach sadowych. Ustawa o kosztach komorniczych. Komentarz, red. M. Simbierowicz, M. Świtkowski, Warszawa 2018.

Gawecki B.J, Propedeutyka filozofii, Warszawa 1938.

Gawecki B.J., Myślenie i postępowanie, Warszawa 1975.

Gołaszewski K., [w:] Ustawa o komornikach sądowych. Ustawa o kosztach komorniczych. Komentarz, red. R. Reiwer, Warszawa 2019.

Harla A.G., Ciężar wspierania postępowania cywilnego przez strony i uczestników postępowania (art. 6 \& 2 k.p.c.), [w:] Księga Pamiatkowa ku czci Sędziego Sąu Najwyższego Prof. dr hab. T. Wiśniewskiego, red. T. Ereciński, Warszawa 2017, s. 195-207.

Harla A.G., Nadzór judykacyjny nad komornikiem wedlug ustawy o komornikach sadowych, [w:] Analiza i ocena ustawy o komornikach sadowych oraz ustawy o kosztach komorniczych, red. A. Marciniak, Sopot 2018, s. 187-202.

Harla A.G., Postulat sprawności postępowania a kwestia jego szybkości (art. 6 k.p.c.), [w:] Kodeks postępowania cywilnego z perspektywy pięćdziesięciolecia jego obowiąywania. Doświadczenia i perspektywy, red. E. Marszałkowska-Krześ, I. Gil, Ł. Błaszczak, Sopot 2016, s. 263-270.

Harla A.G., Prawo upadłościowe i naprawcze. Zarys wykładu, Warszawa 2011.

Harla A.G., Regulacje art. 162 k.p.c. i ich potencjalny wptyw na wykonywanie zobowiazań, [w:] Wykonanie zobowiazań. Ksiega jubileuszowa dedykowana profesorowi Adamowi Brzozowskiemu, red. K. Bilewska, D. Krekora-Zając, Warszawa 2021, s. 165-185.

Harla A.G., Zasada prawdy w procesie cywilnym (art. 2 i art. 232 k.p.c.), [w:] Honeste Procedere. Księga Jubileuszowa dedykowana Profesorowi Kazimierzowi Lubińskiemu, red. A. Laskowska-Hulisz, J. May, M. Mrówczyński, Warszawa, 2017, s. 189-205.

Kopaliński W., Stownik wyrazów obcych i zwrotów obcojęzycznych z almanachem, Warszawa 2003.

Marciniak A., Naduzycie prawa procesowego w sądowym postępowaniu egzekucyjnym, [w:] Nadużycie prawa procesowego cywilnego, red. P. Grzegorczyk, M. Walasik, F. Zedler, Warszawa 2019, s. 348-395. 
Michalunio C., Dicta. Zbiór łacińskich sentencji, przysłów, zwrotów i powiedzeń, Kraków 2004. Muller R.A., Teraz. Fizyka czasu, Warszawa 2018.

Świeczkowska-Wójcikowska M., [w:] Ustawa o komornikach sądowych. Ustawa o kosztach komorniczych. Kodeks Etyki Zawodowej Komornika Sadowego. Komentarz, red. M. Świeczkowska-Wójcikowska, J. Świeczkowski, Warszawa 2020.

Znamierowski C., O poziom studiów prawniczych, „Ruch Prawniczy, Ekonomiczny i Socjologiczny” 1924, nr 4, s. 1021-1028. 